\begin{tabular}{|c|c|c|}
\hline & Int.J.Curr.Microbiol.App.Sci (2016) 5(1): 350-363 & \multirow{4}{*}{ 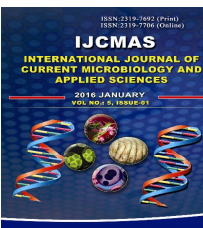 } \\
\hline & International Journal of Current Microbiology and Applied Sciences & \\
\hline & ISSN: 2319-7706 Volume 5 _ Number 1(2016) pp. 350-363 & \\
\hline $\begin{array}{l}\text { EXCELLENT } \\
\text { PUBLISHERS }\end{array}$ & Journal homepage: ihttp://WWW.ijcmas.com & \\
\hline
\end{tabular}

Original Research Article ihttp://dx.doi.org/10.20546/ijcmas.2016.501.033

\title{
Hematological Side Effects of Pegylated Interferon/ Ribavirin Therapy in Chronic HCV Egyptian Patients
}

\author{
Ehab F Mostafa ${ }^{1}$, Mahmoud Saif-Al-Islam², Sahar M Hassany ${ }^{1 *}$, \\ Yehya Rashad Abd-Alrhman ${ }^{3}$ and Mohammed Abd Allah Mohammed ${ }^{4}$ \\ ${ }^{1}$ Department of Tropical Medicine and Gastroenterology, Faculty of Medicine, \\ Assiut University, Egypt \\ ${ }^{2}$ Department of Tropical Medicine and Gastroenterology, Faculty of Medicine, \\ Sohag University, Egypt \\ ${ }^{3}$ Sohag hospital of infecious diseases, Sohag University, Egypt \\ ${ }^{4}$ Clinical Pathology Department, Faculty of Medicine, Sohag University, Egypt \\ *Corresponding author
}

\begin{abstract}
A B S T R A C T
Keywords

Pegylated

Interferon,

Ribavirin

Therapy,

Hepatitis C

virus (HCV),

oral ribavirin

Article Info

Accepted:

16 December 2015

Available Online:

10 January 2016

Hepatitis $\mathrm{C}$ virus (HCV) infection is a major health problem throughout the World. Egypt has the highest worldwide prevalence of HCV (10-20\%). The combination of peginterferon and ribavirin can achieve sustained virologic response in over $50 \%$ of those treated. However, adherence to treatment is critical to maintain high rates of virologic clearance. Unfortunately, peginterferon plus ribavirin therapy can be associated with side effects, some of which may lead to dose reduction, premature discontinuation of the drug, and subsequent treatment failure. is to detect and to manage the hematological side effects of pegylated interferon/ribavirin therapy in chronic HCV in Egyptian patients. This study was done in Sohag city on 500 Egyptian patients who are candidates for pegylated interferon/ ribavirin therapy for chronic HCV. All patients were treated with peginterferon alfa 2a (180 $\mathrm{mcg} /$ week $)$ or peginterferon alfa $2 \mathrm{~b}(1.5 \mathrm{mcg} / \mathrm{kg}$ weekly) subcutaneously plus oral ribavirin in a dose ranging from $800-1200 \mathrm{mg} /$ day for 48 weeks. Baseline pretreatment assessment included quantitative HCV-PCR, liver and kidney functions, complete blood picture, T3 and T4 levels, abdominal ultrasonography, liver biopsy, fundus examination and ECG. Liver functions and complete blood picture were done at the $4^{\text {th }}, 12^{\text {th }}, 24^{\text {th }}$, and $48^{\text {th }}$ weeks. HCV- PCR was followed up at the $12^{\text {th }}, 24^{\text {th }}$, and $48^{\text {th }}$ weeks. During the period of our study, $153(30.6 \%)$ of the studied patients had decrease in hemoglobin level to $10 \mathrm{~g} / \mathrm{dl}$, while severe anemia with hemoglobin level less than $8.5 \mathrm{~g} / \mathrm{dl}$ was found in $33(6.6 \%)$ patients. Reduction of total leucocytic count to 2000 cells $/ \mathrm{mm}^{3}$ was found in $49(9.8 \%)$ patients, while severe neutropenia with neutrophils count less than 750 cells $/ \mathrm{mm}^{3}$ was found in $12(2.4 \%)$ patients. Asymptomatic thrombocytopenia with platelets count from 50000 to $150000 / \mathrm{mm}^{3}$ was found in $141(28.2 \%)$ patients, while severe thrombocytopenia with platelets count less than $50000 / \mathrm{mm}^{3}$ was found in $3(0.6 \%)$ patients. the hematological side effects of pegylated interferon and ribavirin are anemia, leucopenia, and thrombocytopenia in $30.6 \%, 9.8 \%$ and $34 \%$ of the patients during the course of the treatment. These side effects can be managed by dose reduction or stoppage and by administration of erythropoietin and Granulocyte colony-stimulating factor (G-CSF).
\end{abstract}




\section{Introduction}

Hepatitis $\mathrm{C}$ virus (HCV) infection is a major health problem throughout the world. Recent estimates indicate that 175 million people are infected (1). Egypt has the highest worldwide prevalence of HCV (10-20\%). More than $90 \%$ of $\mathrm{HCV}$ isolates from Egyptian patients are of the genotype 4 variant $(2,3)$. In rural areas of Egypt the prevalence of $\mathrm{HCV}$ reaches $24 \%$. Other countries where genotype 4 is prevalent include the equatorial and west-central African nations of Gabon, Tanzania, Libya, and Zaire, where seroprevalence can reach up to $8 \%$ (4).

Antiviral therapy for chronic hepatitis $\mathrm{C}$ has many goals; the primary goal is durable viral clearance as evidenced by the absence of HCV RNA in serum (virological response); the secondary goal is reduction of damage to the liver as determined by either persistently normal ALT levels (biochemical response) or improved liver biopsy, with the expectation that this will delay or prevent cirrhosis and HCC (5).

The combination of peginterferon and ribavirin can achieve sustained virologic response in over $50 \%$ of those treated. However, adherence to treatment is critical to maintain high rates of virologic clearance (6). Unfortunately, peginterferon plus ribavirin therapy can be associated with side effects, some of which may lead to dose reduction, premature discontinuation of the drug, and subsequent treatment failure (7).

Interferon (IFN) induced thrombocytopenia and leucopenia are common whereas anaemia is more a sequela of combination therapy with ribavirin (8). Thrombocytopenia is mild in most cases, amounting to a decrease in peripheral platelet count to $10-50 \%$ but, when severe, can lead to bleeding complications $(9,10)$ and discontinuation of IFN therapy (6). Absolute neutrophil and lymphocyte counts typically decrease by $30-50 \%$ of baseline values during IFN therapy but this is usually not associated with infection (11).

The main mechanism leading to cytopenia during IFN therapy seems to be bone marrow suppression by IFN (8). Immune mediated hematological toxicity and capillary sequestration of platelets and white blood cells have been proposed as additional causes of severe thrombocytopenia and leucopenia during IFN therapy (10).

Ribavirin causes dose-dependent hemolytic anemia, and interferon can suppress bone marrow production of red blood cells. This result in anemia, which is likely in more than $20 \%$ of patients treated with pegylated interferon and ribavirin $(12,13)$. We aimed of this work is to detect and to manage the hematological side effects of pegylated interferon/ribavirin therapy in chronic $\mathrm{HCV}$ in Egyptian patients.

\section{Materials and Methods}

This study was done in Sohag city on 500 Egyptian patients who are candidates for pegylated interferon/ ribavirin therapy for chronic HCV (after a written consent). All patients were treated with peginterferon alfa $2 \mathrm{a}(180 \mathrm{mcg} /$ week) or peginterferon alfa $2 \mathrm{~b}$ $(1.5 \mathrm{mcg} / \mathrm{kg}$ weekly) subcutaneously plus oral ribavirin in a dose ranging from 800$1200 \mathrm{mg} /$ day for 48 weeks.

\section{Pre-treatment Evaluation}

I- Complete history taking and thorough clinical examination. 
II- Laboratory investigations:

1- HCV Ab was carried out using fully automated ELISA (Axsym).

2- Quantitative HCV RNA level by PCR: for estimation of viral load, the test was carried out using the real time PCR system.

3- Liver functions and renal functions: including albumin, AST and ALT levels, which were carried out using the fully automated chemical analyzer (Bechman Caulter Alex 9).

4- Prothrombin time and INR using sysmex ca 1500 system.

5- Complete blood count (CBC) was carried out using the fully automated cell counter celldyn 3700. Pre-existing leucopenia or thrombocytopenia is a relative contraindication to treatment of $\mathrm{HCV}$ infection.

6- Thyroid profile: as a base line, as autoimmune thyroiditis can be caused or exacerbated by pegylated interferon. It was carried out using fully automated ELISA (Axsym).

III- Abdominal ultrasonography: to evaluate liver size and parenchyma and exclude ascites.

IV- Liver biopsy: to determine the grade of inflammation and the stage of fibrosis.

V- Upper GIT endoscopy: to exclude esophageal varices.

VI- Fundus examination.

VII- Electrocardiography (ECG).

\section{Inclusion Criteria}

Patients with chronic HCV who are candidates for interferon/ ribavirin therapy:

- Age is from 18 to 60 years.

\section{Liver Biopsy}

Minimal changes in the liver biopsy with Metavir score >A1 and >F0 with elevated liver enzymes.

Those with normal liver enzymes and Metavir score $\geq \mathrm{A} 2$ and $\geq \mathrm{F} 2$.

Quantitative HCV PCR was done before treatment and after 12 weeks of treatment. Therapy will continue only for responders and those with more than $2 \log$ decrease in viral load after 12 weeks of treatment.

Qualitative HCV PCR was done after 24 weeks of treatment and therapy will continue only if PCR is negative.

Compensated liver cirrhosis (Child A) will be treated if there is no varix.

\section{Exclusion Criteria}

Body mass index (BMI) >35 will not be treated except after body weight reduction.

Patients with contraindication to interferon/ ribavirin therapy:

- Non-compliant or psychosocially unstable patient with active psychosis, major depression, active autoimmune disease, active bacterial infection (e.g. osteomyelitis).

- Pregnancy or lack of appropriate contraception (male and female, as ribavirin is teratogenic). 
- Significant comorbidity such as renal failure, heart disease or uncontrolled diabetes mellitus.

- Decompensated liver disease.

- Males with hemoglobin less than $13 \mathrm{~g} / \mathrm{dl}$ and females with hemoglobin less than 12 $\mathrm{g} / \mathrm{dl}$.

- Platelets count less than $150000 / \mathrm{mm}^{3}$ or white blood cells less than $4000 / \mathrm{mm}^{3}$ or neutrophil count less than $1500 / \mathrm{mm}^{3}$.

Monitoring and Follow up of Patients During the Course of Treatment (to Detect Possible Complications of Therapy)

I-Complete history taking and thorough clinical examination: with special stress on:

- Constitutional symptoms like fatigue, headache, myalgia and fever.

- Gastrointestinal symptoms like nausea, anorexia and diarrhea.

- Symptoms suggestive of psychiatric side effects like insomnia, irritability and depression.

- Symptoms suggestive of any visual changes.

- Skin examination to detect the presence of hair loss or skin rash.

II- Laboratory investigations with special stress on:

- $\mathrm{CBC}$ : to detect any possible hematological side effects.

- Liver profile including AST and ALT levels.

- Liver function tests and CBC were done regularly at $4^{\text {th }}, 12^{\text {th }}, 24^{\text {th }}$ and $48^{\text {th }}$ weeks.

- Renal profile including serum urea and creatinine.

- The level of HCV RNA post-treatment to determine the pattern of virological response. HCV PCR was fallowed up at $12^{\text {th }}, 24^{\text {th }}$ and $48^{\text {th }}$ weeks.

III- Abdominal ultrasonography.

IV- Psychiatric, hematological, dermatological or ophthalmological consultations were done when needed.

\section{Treatment was Reduced to Half of the Dose in the Following}

- Hemoglobin level ranging from $8.5 \mathrm{~g} / \mathrm{dl}$ to $10 \mathrm{~g} / \mathrm{dl}$ (reduce the dose of ribavirin to $600 \mathrm{mg}$ ).

- Platelets count ranging from $25000 / \mathrm{mm}^{3}$ to $50000 / \mathrm{mm}^{3}$.

- White blood cells count less than $1500 / \mathrm{mm}^{3}$.

- Neutrophiles count less than $750 / \mathrm{mm}^{3}$.

Treatment was Discontinued in the Following

- Patients with positive HCV PCR after 12 weeks.

- Hemoglobin level less than $8.5 \mathrm{~g} / \mathrm{dl}$ (stop ribavirin).

- Platelets count less than $25000 / \mathrm{mm}^{3}$.

-White blood count less than $1000 / \mathrm{mm}^{3}$. 
- Neutrophiles count less than 500/ $\mathrm{mm}^{3}$. Results and Discussion

This study was conducted on 500 consecutive patients with proven chronic hepatitis $\mathrm{C}$ virus. The baseline demographic and laboratory characteristics of the studied patients were shown in Table 1 . The mean age was $41.66 \pm 10.32$ years. All patients had normal baseline blood indices as a prerequisite for initiating treatment.

Anemia with hemoglobin levels below 10 $\mathrm{g} / \mathrm{dl}$ was detected in $3.2 \%$ of cases at the $4^{\text {th }}$ week, $11 \%$ of cases at the $12^{\text {th }}$ week, $9 \%$ of cases at the $24^{\text {th }}$ week and $3 \%$ of cases at the $48^{\text {th }}$ week. The highest frequency of anemia reaching $11 \%$ was found at the $12^{\text {th }}$ week. None of the patients developed anemia with hemoglobin below $6.4 \mathrm{~g} / \mathrm{dl}$ (Table 2).

$30.6 \%$ of the studied patients had decrease in hemoglobin to $10 \mathrm{~g} / \mathrm{dl}$, while $69.4 \%$ of the patients did not have anemia during the course of treatment. $19.4 \%$ of the cases had anemia at one time point, $9.2 \%$ of the cases had anemia at two time points, $1.2 \%$ of the cases had anemia at three time points and $0.8 \%$ of the cases had anemia at four time points during treatment (Figure 1).

Ribavirin dose was reduced when hemoglobin level reached below $10 \mathrm{~g} / \mathrm{dl}$ and the patient received erythropoietin. In our study, 8.4\% (42/500) discontinued INF and RBV combination therapy because of anemia.

There was highly significant difference in baseline characteristics between patients who developed anemia and those who did not. Patients who developed anemia had older age, male sex preponderance, higher body mass index, lower base line hemoglobin level, higher levels of ALT and higher viremia by PCR (Table 3).

Significant leucopenia with WBC count $<2000 \mathrm{cell} / \mathrm{mm}^{3}$ was detected in $0.6 \%$ of cases at the $4^{\text {th }}$ week, $1.4 \%$ of cases at the $12^{\text {th }}$ week, $2.6 \%$ of cases at the $24^{\text {th }}$ week and $2 \%$ of cases at the $48^{\text {th }}$ week (Table 4 ).

$90.2 \%$ of the patients did not have significant leucopenia during the course of treatment. $5.8 \%$ of the cases had leucopenia at one time point, $1.6 \%$ of the cases had leucopenia at two time points, $1.4 \%$ of the cases had leucopenia at three time points and $1 \%$ of the cases had leucopenia at four time points during treatment (Figure 2).

There was highly significant difference in baseline characteristics between patients who developed significant leucopenia and those who did not. Patients who developed significant leucopenia had older age, male sex preponderance, higher body mass index, higher levels of ALT and higher viremia by PCR (Table 5).

Asymptomatic thrombocytopenia with platelets count ranging from 150000 to $50000 / \mathrm{mm}^{3}$ was detect in $16 \%$ of the patients at the $4^{\text {th }}$ week, $17.4 \%$ at the $12^{\text {th }}$ week, $20 \%$ at the $24^{\text {th }}$ week and $14.8 \%$ at the $48^{\text {th }}$ week (Table 6).

$71.8 \%$ of the patients did not have asymptomatic thrombocytopenia during the course of treatment. $10 \%$ of the cases had asymptomatic thrombocytopenia at one time point, $9.6 \%$ of the cases had asymptomatic thrombocytopenia at two time points, $5.2 \%$ of the cases had asymptomatic thrombocytopenia at three time points, and $3.4 \%$ of the cases had asymptomatic thrombocytopenia at four time points during treatment (Figure 3).

There was highly significant difference in 
baseline characteristics between patients who developed asymptomatic thrombocytopenia and those who did not. Patients who developed asymptomatic thrombocytopenia were younger, had lower body mass index, had higher levels of ALT and lower levels of viremia by PCR. There is no significance difference between males and females regarding the development of thrombocytopenia (Table 7).

Severe anemia with hemoglobin level below $8.5 \mathrm{~g} / \mathrm{dl}$ was present in $6.6 \%$ patients, severe neutropenia below 750 cells $/ \mathrm{mm}^{3}$ was present in $2.4 \%$ patients, severe thrombocytopenia below $50000 / \mathrm{mm}^{3}$ was present in $0.6 \%$ patients, mild to moderate anemia with hemoglobin level between 8.5$10 \mathrm{~g} / \mathrm{dl}$ was present in $30.6 \%$ patients, and asymptomatic thrombocytopenia with platelets count from $150000-50000 / \mathrm{mm}^{3}$ was present in $34 \%$ patients. The lowest leucocytic count was 1.2 cells/ $\mathrm{mm}^{3}$ and it was found in $0.6 \%$ patients (Table 8 ).

Figure (4) summarizes all the hematological side effects which had occurred all over the course of treatment. Anemia, leucopenia and asymptomatic thrombocytopenia, were found in $3.2 \%, 0.6 \%$ and $16 \%$ patients at the $4^{\text {th }}$ week; $11 \%, 1.4 \%$ and $17.4 \%$ patients at the $12^{\text {th }}$ week; $9 \%, 2.6 \%$ and $20 \%$ patients at the $24^{\text {th }}$ week; $3 \%, 2 \%$ and $14.8 \%$ patients at the $48^{\text {th }}$ week respectively.

Table.1 Baseline Demographic and Laboratory Characteristics of the 500 Studied Patients

\begin{tabular}{|l|c|c|}
\hline & Mean & Standard deviation \\
\hline Age & 41.66 & \pm 10.32 \\
\hline Weight & 73.48 & \pm 12.02 \\
\hline Height & 169.63 & \pm 6.07 \\
\hline Body mass index & 25.53 & \pm 3.88 \\
\hline ALT & 38.79 & \pm 39.79 \\
\hline Hemoglobin & 14.81 & \pm 1.53 \\
\hline White blood cell & 6.46 & \pm 2.06 \\
\hline Platelets & 235900 & \pm 53.62 \\
\hline Ribavirin & 1028.4 & \pm 164.34 \\
\hline PCR & 771979.38 & \pm 161966.0 \\
\hline
\end{tabular}

ALT: alanine aminotransferase

PCR: polymerase chain reaction

Table.2 Anemia During the Course of Treatment among the 500 Studied Patients

\begin{tabular}{|c|c|c|}
\hline \multirow{2}{*}{ Follow up time } & \multicolumn{2}{|c|}{ Hemoglobin $<\mathbf{1 0}$ g/dl } \\
\cline { 2 - 3 } & Number & Percent \\
\hline $4^{\text {th }}$ week & 16 & 3.2 \\
\hline $\mathbf{1 2}^{\text {th }}$ week & 55 & 11.0 \\
\hline $\mathbf{2 4}^{\text {th }}$ week & 45 & 9.0 \\
\hline $\mathbf{4 8}^{\text {th }}$ week & 15 & \\
\hline
\end{tabular}




\begin{tabular}{|l|l|l|}
\hline & & 3.0 \\
\hline
\end{tabular}

Table.3 Comparison Between Patients with and without Anemia

\begin{tabular}{|c|c|c|c|}
\hline & $\begin{array}{l}\text { Patients with anemia } \\
\text { (153) }\end{array}$ & $\begin{array}{l}\text { Patient without anemia } \\
\text { (347) }\end{array}$ & P value \\
\hline Age & $44.07 \pm 10.49$ & $40.60 \pm 10.07$ & 0.0001 \\
\hline Male:female & $125: 28$ & $322: 25$ & 0.0001 \\
\hline $\begin{array}{l}\text { Body mass } \\
\text { index }\end{array}$ & $25.83 \pm 3.48$ & $25.40 \pm 4.04$ & 0.0001 \\
\hline $\begin{array}{l}\text { Base line } \\
\text { hemoglobin } \\
\text { level }\end{array}$ & $13.9 \pm 1.45$ & $15.07 \pm 1.44$ & 0.0001 \\
\hline ALT & $42.96 \pm 50.71$ & $36.95 \pm 33.81$ & 0.0001 \\
\hline PCR & $871748.7 \pm 2285340.0$ & $727988.9 \pm 1217617.0$ & 0.0001 \\
\hline
\end{tabular}

ALT: alanine aminotransferase

PCR: polymerase chain reaction

Table.4 Significant Leucopenia during the Course of Treatment among the 500 Studied Patients

\begin{tabular}{|c|c|c|}
\hline \multirow{2}{*}{ Follow up time } & \multicolumn{2}{|c|}{ WBC $<2000$ cell/mm } \\
\hline & Number & Percent \\
\hline $4^{\text {th }}$ week & 3 & 0.6 \\
\hline $\mathbf{1 2}^{\text {th }}$ week & 7 & 1.4 \\
\hline $\mathbf{2 4}^{\text {th }}$ week & 13 & 2.6 \\
\hline $\mathbf{4 8}^{\text {th }}$ week & 10 & 2.0 \\
\hline
\end{tabular}

WBC: white blood cells

Table.5 Comparison between Patients with and without Significant Leucopenia during the Course of Treatment

\begin{tabular}{|l|c|c|c|}
\hline & $\begin{array}{c}\text { Patients with significant } \\
\text { leucopenia (49) }\end{array}$ & $\begin{array}{c}\text { Patients without significant } \\
\text { leucopenia (451) }\end{array}$ & P value \\
\hline Age & $44.96 \pm 10.44$ & $40.72 \pm 10.10$ & 0.0001 \\
\hline Male:female & $89: 22$ & $358: 31$ & 0.0001 \\
\hline Body mass index & $25.82 \pm 3.83$ & $25.57 \pm 3.89$ & 0.0001 \\
\hline ALT & $45.96 \pm 37.43$ & $39.59 \pm 40.45$ & 0.0001 \\
\hline PCR & $1042740 \pm 2644491$ & $694718.6 \pm 116798.7$ & 0.0001 \\
\hline
\end{tabular}


ALT: alanine aminotransferase

PCR: polymerase chain reaction

Table.6 Frequency of Asymptomatic Thrombocytopenia during the Course of Treatment Among the 500 Studied Patients

\begin{tabular}{|c|c|c|}
\hline \multirow{2}{*}{ Follow up time } & \multicolumn{2}{|c|}{$\begin{array}{c}\text { Asymptomatic thrombocytopenia <150000- } \\
\mathbf{5 0 0 0 0} \text { - }\end{array}$} \\
\cline { 2 - 3 } $\mathbf{4}^{\text {th }}$ week & 80 & Percent \\
\hline $\mathbf{1 2}^{\text {th }}$ week & 87 & 16.0 \\
\hline $\mathbf{2 4}^{\text {th }}$ week & 100 & 17.4 \\
\hline $\mathbf{4 8}^{\text {th }}$ week & 74 & 20.0 \\
\hline
\end{tabular}

Table.7 Comparison between Patients with and without Asymptomatic Thrombocytopenia during the Course of Treatment

\begin{tabular}{|l|c|c|c|}
\hline & $\begin{array}{c}\text { Patients with } \\
\text { asymptomatic } \\
\text { thrombocytopenia (141) }\end{array}$ & $\begin{array}{c}\text { Patients without } \\
\text { thrombocytopenia (359) }\end{array}$ & P value \\
\hline Age & $38.68 \pm 10.3$ & $43.2 \pm 10$ & 0.0001 \\
\hline Male:female & $153: 17$ & $294: 36$ & 0.754 \\
\hline Body mass indes & $25.28 \pm 3.93$ & $25.37 \pm 3.85$ & 0.0001 \\
\hline ALT & $47.45 \pm 39$ & $34.33 \pm 39.51$ & 0.0001 \\
\hline PCR & $699553 \pm 2065266$ & $809289.9 \pm 1335558$ & 0.0001 \\
\hline
\end{tabular}

ALT: alanine aminotransferase

PCR: polymerase chain reaction

Table.8 Severe Side Effects of Therapy

\begin{tabular}{|c|c|c|}
\hline & Number & percent \\
\hline $\begin{array}{l}\text { Severe anemia (hemoglobin }<8.5 \\
\text { g/dl) }\end{array}$ & 33 & 6.6 \\
\hline $\begin{array}{l}\text { Severe neutropenia (neutophils }<750 \\
\text { cells } / \mathbf{m m}^{3} \text { ) }\end{array}$ & 12 & 2.4 \\
\hline $\begin{array}{l}\text { Severe thrombocytopenia (platelets < } \\
50000 / \mathrm{mm}^{3} \text { ) }\end{array}$ & 3 & 0.6 \\
\hline $\begin{array}{l}\text { Mild to moderate anemia } \\
(\text { hemoglobin }=8.5-10 \mathrm{~g} / \mathrm{dl})\end{array}$ & 153 & 30.6 \\
\hline $\begin{array}{l}\text { Asympatomatic thrombocytopenia } \\
\left(\text { platelets }=50000-150000 / \mathrm{mm}^{3}\right)\end{array}$ & 170 & 34 \\
\hline Lowest leucocytic count 1.2 cells $/ \mathrm{mm}^{3}$ & 3 & $0.6 \%$ \\
\hline
\end{tabular}


Int.J.Curr.Microbiol.App.Sci (2016) 5(1): 350-363 
Figure.1 Frequency of Anemia among the Patients during the Course of Treatment

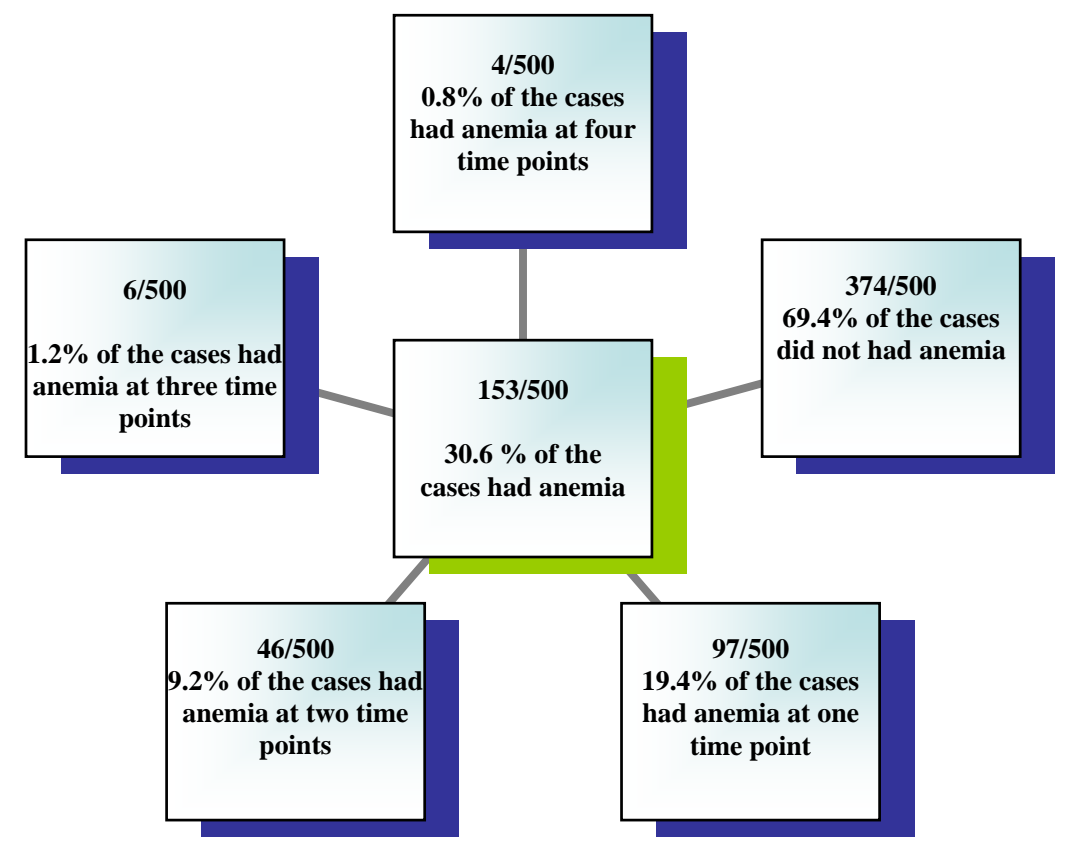

Figure.2 Frequency of Significant Leucopenia among the Patients during the Course of Treatment

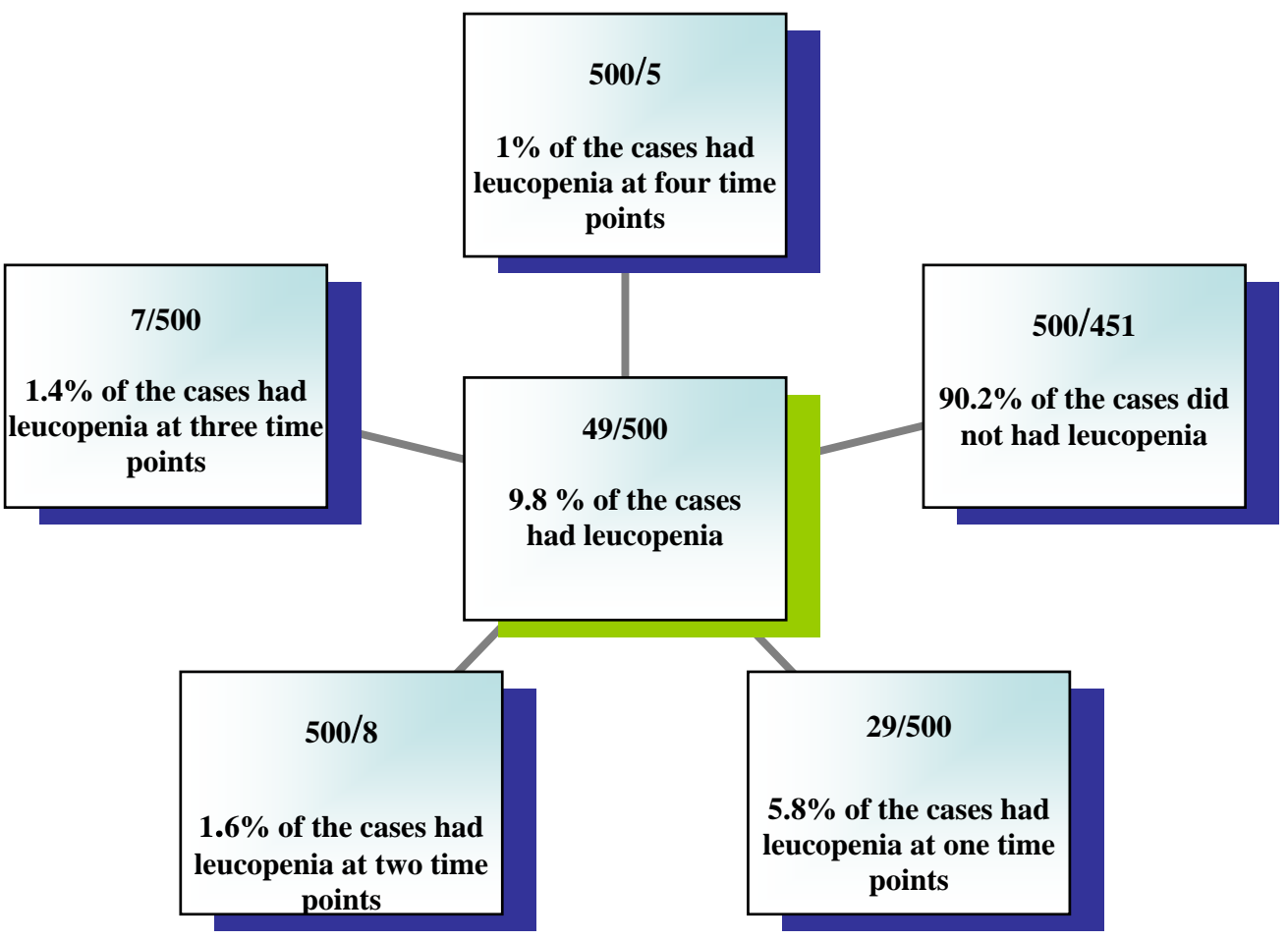


Figure.3 Frequency of Asymptomatic Thrombocytopenia among Patients during the Course of Treatment

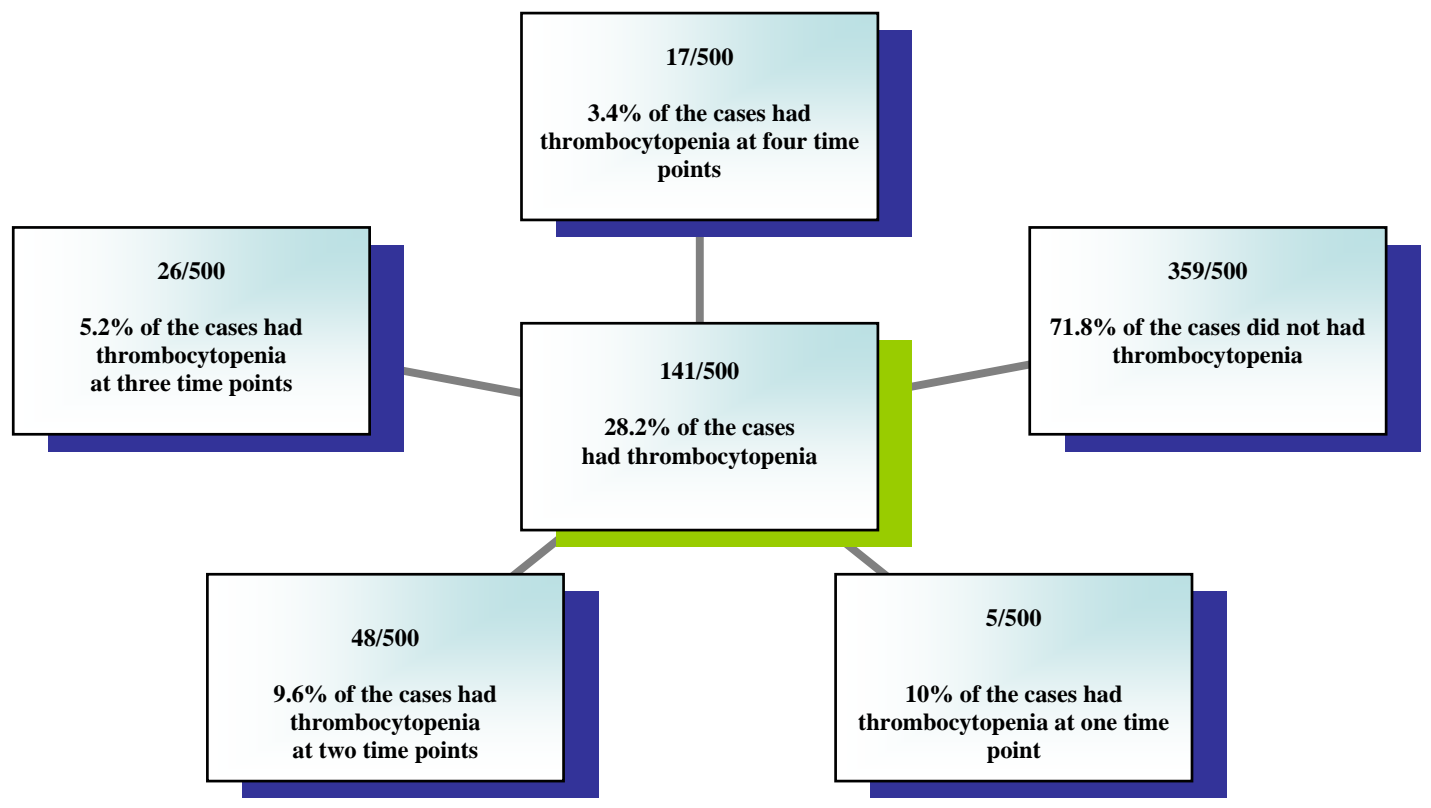

Figure.4 Summary of Hematological Side Effects during Treatment

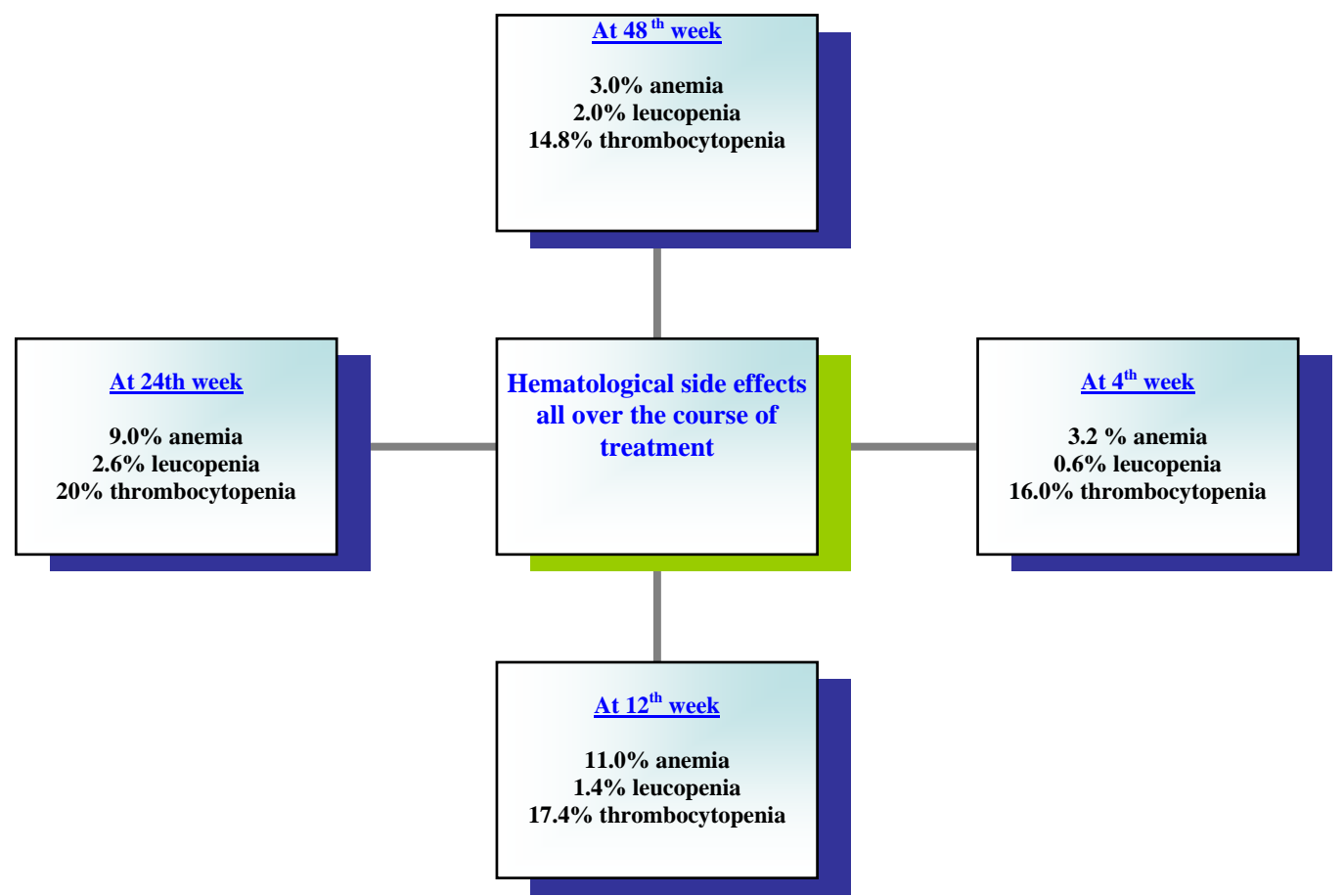


The number of patients for whom ribavirin dose was reduced due to decrease of hemoglobin level to $10-8.5 \mathrm{~g} / \mathrm{dl}$ and received erythropoietin was $111(22.2 \%)$ patients, while the number of patient who stopped the treatment due to decrease of hemoglobin below 8.5 was $42(8.4 \%)$ patients and also received erythropoietin.

The number of patients for whom interferon dose was reduced due to decrease neutrophil count below 750 cells $/ \mathrm{mm}^{3}$ was 12 (2.4) and received Granulocyte colony-stimulating factor (G-CSF).

In our study we followed 500 patients infected by chronic $\mathrm{HCV}$ receiving peginterferon alpha $2 \mathrm{a}(180 \mathrm{mcg} /$ week $)$ or peginterferon alfa- $2 \mathrm{~b}(1.5 \mathrm{mcg} / \mathrm{kg}$ weekly $)$ subcutaneously plus oral ribavirin in a dose ranging from 800-1200 $\mathrm{mg} /$ day for 48 weeks. Our aim was to detect and to manage the hematological side effects of peginterferon alpha ( $2 \mathrm{a}$ or $2 \mathrm{~b})$ and ribavirin.

In our study, $30.6 \%$ of the studied patients had decrease in hemoglobin to $10 \mathrm{~g} / \mathrm{dl}$. The incidence of anemia in different weeks of treatment was $3.2 \%$ at $4^{\text {th }}$ week, $11 \%$ at $12^{\text {th }}$ week, $9 \%$ at $24^{\text {th }}$ week and $3 \%$ at $48^{\text {th }}$ week. Recent trials have demonstrated that higher starting doses of ribavirin can improve SVR rates in difficult-to-treat populations. Early indicators of subsequent considerable anemia should prompt the physician to consider early and small reductions in ribavirin dose (200 $\mathrm{mg}$ decrements) to reduce the risk of considerable anemia while maintaining adequate exposure to ribavirin $(14,15)$. The use of recombinant human erythropoietin is not an easy option in Egypt where the therapy costs represent a major problem that limits adherence to therapy.

The results of the current study are in agreement with that of Fried who found that more than $20 \%$ of patients treated with pegylated interferon and ribavirin (in a dose of $1000-1200 \mathrm{mg} /$ day) had anemia (16). We found that $8.4 \%$ of the patients discontinued IFN and RBV combination therapy because of anemia. However, Saito and coworkers found that $14.5 \%$ of the patients discontinued IFN and RBV combination therapy because of anemia (17).

The anemia is probably multifactorial in most cases. Some degree of hemolysis is virtually universal in patients receiving RBV. Erythrocytes selectively accumulate RBV metabolites, sustain oxidative membrane damage and become subject to increased extravascular hemolysis in the reticuloendothelial system. In addition, IFNs can directly suppress bone marrow erythropoiesis, thus impairing the response to RBV-induced hemolysis. Ribavirin itself has also been reported to have myelosuppressive properties (18).

In our study, we identified several independent factors, including older age, male sex, higher body mass index, lower base line hemoglobin level, higher ALT levels and higher viremia by PCR that were predictive of subsequent development of considerable decrease in hemoglobin, allowing the opportunity to identify patients at heightened risk of developing anemia even before starting therapy.

We found that, male gender, ages above forty years, body mass index more than 25 , ALT above 42 and hepatitis $C$ viremia more than 800000 were shown to be independent predictors of considerable decrease in hemoglobin in the multiple logistic regression analysis (both $\mathrm{p}<0.0001$ ). Our results and those of others clearly show that anemia is a common and significant problem during treatment with interferon and ribavirin. A decline in hemoglobin begins shortly after initiation of treatment and generally reaches the lowest level after 4 to 8 weeks of therapy (19). Indeed, treatment- 
induced anemia has been shown to be one of the most frequently reported adverse events and contributes to dose reductions and treatment discontinuations $(7,19)$.

As regards total leucocytic count, we found that $9.8 \%$ had decreased WBCs count to less than 2000 cell $/ \mathrm{mm}^{3}$ during the treatment. The incidence of leucopenia in different weeks of treatment was $0.6 \%$ at the $4^{\text {th }}$ week, $1.4 \%$ at the $12^{\text {th }}$ week, $2.6 \%$ at the $24^{\text {th }}$ week and $2 \%$ at the $48^{\text {th }}$ week. Aspinall and Pockros found that patients receiving PEG-IFN alpha -2a combination or monotherapy experience significant neutropenia in approximately $20 \%$ of cases. Dose reductions occurred in monotherapy and combination therapy trials of PEG-IFN alpha $-2 \mathrm{a}$ and RBV in $17-20 \%$ of individuals (18). Although anemia and leucopenia are reversible when therapy is discontinued, these hematological disorders have considerable impact on treatment outcome in relation to adequate ribavirin dosing (6).

Platelets counts were shown to drop during interferon and ribavirin therapy, due to interferon suppression of platelets production in the bone marrow. In our study $14.8 \%$ patients developed thrombocytopenia at the $48^{\text {th }}$ week of therapy, and only $0.6 \%$ developed severe thrombocytopenia below $50000 / \mathrm{mm}^{3}$ during the course of treatment with subsequent dose reduction.

Aspinall and Pockros reported that interferon therapy frequently results in a 10$50 \%$ fall in the platelets count, although this is rarely of clinical significance. Possible mechanisms include a relative thrombopoietin deficiency, impaired thrombopoietin signal transduction in megakaryocytes, hypersplenism and in some cases increased immune-mediated sequestration of platelets (18).

In the trial reported by Fried only around 4-
$6 \%$ of patients receiving PEG-IFN alpha $-2 \mathrm{a}$ and $\mathrm{RBV}$ required dose reduction for thrombocytopenia (16).

In conclusion the hematological side effects of pegylated interferon and ribavirin are anemia, leucopenia, and thrombocytopenia in $30.6 \%, 9.8 \%$ and $34 \%$ of the patients during the course of the treatment. These side effects can be managed by dose reduction or stoppage and by administration of erythropoietin and Granulocyte colony stimulating factor (G-CSF). Pegylated interferon and ribavirin proper doses are critical to the successful treatment of HCV and they should be initiated at the highest appropriate dose and maintained for as long as possible with appropriate management of the hematological side effects.

\section{References}

1.Hnatyszyn HJ (2005): Chronic hepatitis C and genotyping: The clinical significance of determining $\mathrm{HCV}$ genotypes. Antivir Ther; 10 (1):1-11.

2.Ray SC, Arthur RR, Carella A, Bukh J, Thomas DL (2000): Genetic epidemiology of hepatitis C virus throughout Egypt. J Infect Dis; 182 (3):698-707.

3.Kamal SM and Nasser IA (2008): Hepatitis C genotype 4: What we know and what we don't yet know. Hepatology; 47(4): 1371-83.

4.Abdel-Aziz F, Habib M, Mohamed MK, Abdel-Hamid M, Gamil F, Madkour S, Mikhail NN, Thomas D, Fix AD, Strickland GT, Anwar W, Sallam I (2000): Hepatitis C virus (HCV) infection in a community in the Nile Delta: population description and $\mathrm{HCV}$ prevalence. Hepatology; 32 (1):111-5.

5.Manns MP, Wedemeyer H, Cornberg M (2006): Treating viral hepatitis C: efficacy, side effects, and 
complications. Gut; 55 (9): 1350-9.

6.McHutchison JG, Manns M, Patel K, Poynard T, Lindsay KL, Trepo C, Dienstag J, Lee WM, Mak C, Garaud JJ, Albrecht JK (2002): Adherence to combination therapy enhances sustained response in genotype-1infected patients with chronic hepatitis C. Gastroenterology; 123 (4):1060-9.

7.Sulkowski MS, Wasserman R, Brooks L, Ball L, Gish R (2004): Changes in haemoglobin during interferon alpha$2 \mathrm{~b}$ plus ribavirin combination therapy for chronic hepatitis $\mathrm{C}$ virus infection. J. Viral Hepat; 11 (3):243-50.

8.Russo MW and Fried MW (2003): Side effects of therapy for chronic hepatitis C. Gastroenterology; 124 (6):1711-9.

9.Soza A, Everhart JE, Ghany MG, Doo E, Heller T, Promrat K, Park Y, Liang TJ, Hoofnagle JH (2002): Neutropenia during combination therapy of interferon alfa and ribavirin for chronic hepatitis C. Hepatology; 36 (5):1273-9.

10.Wang Q, Miyakawa Y, Fox N, Kaushansky K (2000): Interferonalpha directly represses megakaryopoiesis by inhibiting thrombopoietin-induced signaling through induction of SOCS-1. Blood; 96 (6): 2093-9.

11.Schmid M, Kreil A, Jessner W, Homoncik M, Datz C, Gangl A, Ferenci P, Peck-Radosavljevic M (2005): Suppression of hematopoiesis during therapy of chronic hepatitis $\mathrm{C}$ with different interferon alpha mono and combination therapy regimens. Gut; 54 (7):1014-20.

12.Manns MP, McHutchison JG, Gordon SC, Rustgi VK, Shiffman M, Reindollar R, Goodman ZD, Koury K, Ling M, Albrecht JK (2001): Peginterferon alfa- $2 b$ plus ribavirin compared with interferon alfa- $2 b$ plus ribavirin for initial treatment of chronic hepatitis C: a randomized trial. Lancet; 358 (9286): 958-65.

13.Torriani FJ, Rodriguez-Torres $\mathrm{M}$, Rockstroh JK, Lissen E, GonzalezGarc $\square$ a J, Lazzarin A, Carosi G, Sasadeusz J, Katlama C, Montaner J, Sette H Jr, Passe S, De Pamphilis J, Duff F, Schrenk UM, Dieterich DT (2004): Peginterferon alfa-2a plus ribavirin for chronic hepatitis $\mathrm{C}$ virus infection in HIV-infected patients. N Engl J Med; 351 (5):438-50.

14.Shiffman ML, Salvatore J, Hubbard S, Price A, Sterling RK, Stravitz RT, Luketic AV, Sanyal AJ (2007): Treatment of chronic hepatitis $C$ virus genotype 1 with peginterferon, ribavirin, and epoetin alpha. Hepatology; 46 (2): 371-9.

15.Jacobson IM, Brown RS Jr, Freilich B, Afdhal N, Kwo PY, Santoro J, Becker S, Wakil AE, Pound D, Godofsky E, Strauss R, Bernstein D, Flamm S, Pauly MP, Mukhopadhyay P, Griffel LH, Brass CA (2007): Peginterferon alfa- $2 b$ and weight-based or flat-dose ribavirin in chronic hepatitis $\mathrm{C}$ patients: a randomized trial. Hepatology; 46 (4): 971-81.

16.Fried MW (2002): Side effects of therapy of hepatitis $\mathrm{C}$ and their management. Hepatology; 36(5 Suppl 1):S237-44.

17.Saito H, Tada S, Ebinuma H, Ishii H, Kashiwazaki K, Takahashi M, Tsukada N, Nishida J, Tanaka S, Shiozaki H, Hibi T (2006): Role of Erythrocytes as a reservoir for ribavirin and relationship with adverse reactions in the early phase of interferon combination therapy for chronic hepatitis $\mathbf{C}$ virus infections. J Clin Microbiol; 44 (10): 3562-8.

18.Aspinall RJ and Pockros PJ (2004): The management of side effects during therapy for hepatitis C. Aliment 
Pharmacol Ther; 20 (9):917-29.

19.Takaki S, Tsubota A, Hosaka T, Akuta N, Someya T, Kobayashi M, Suzuki F, Suzuki Y, Saitoh S, Arase Y, Ikeda K, Kumada H (2004): Factors contributing to ribavirin dose reduction due to anemia during interferon alfa 2 $\mathrm{b}$ and ribavirin combination therapy for chronic hepatitis C. J Gastroentrol; 39 (7): 668-73.

\section{How to cite this article:}

Ehab F Mostafa, Mahmoud Saif-Al-Islam, Sahar M Hassany, Yehya Rashad Abd-Alrhman and Mohammed Abd Allah Mohammed. 2016. Hematological Side Effects of Pegylated Interferon/ Ribavirin Therapy in Chronic HCV Egyptian Patients. Int.J.Curr.Microbiol.App.Sci. 5(1): 350363. hittp://dx.doi.org/10.20546/ijcmas.2016.501.033 